new double-stars; on the transit of Mercury, November 8, 188r, by H. C. Russell.-On the inorganic constituents from epiphytic ferns, by W. A. Dixon.-A census of the genera of plants native to Australia, by Baron Ferd. von Mueller.-On water storage and canalisation for the colony, by F. B. Gipp:

Rivista Scientifico-Industriale e Fournale del Naturalista, Septembe: 15.- Luni-solar influence on earthquake;, by F. L. Bombicci.--On the transformation of electricity into voltaic currents, and the application of these currents, by G. Govö.Doderlein's ichthyological manual of the Mediterranean, by $\mathrm{E}$. Riggio.

Archives des Sciences Physiques et Naturelles, September 15. -On the rotatory polarisation of quartz (third part), by MM. Soret and Sarasin.-The pelagic fauna of freshwater lakes, by F. A. Forel.--Researches on the quantity of carbonic acid contained in the atmospheric air, by E. Risler. - The air thermometer arranged with a view to a determination of high tempera tures in practice, by $\mathrm{H}$. Schneebeli.-Remarks on M. Louis Lossier's work, entitled "Electrolytic Calculations," by C. E. Guillaume.-Geometric proof of the theorem of Wheatstone's bridge. by the same. - Emile Plantamour.

Bulletin de l'Academie Imperiale des Sciences de St. Petersbourg, Part xxviii., No. 2.-New researches on artificial double stars, by O. Struve. - Topographical observations of Jupiter, by J. Kalazzi.-On the oxidation of isodibutylene by hypermanganate of potash, by A. B outlerov.-Observations of the planets Jupiter, Saturn, and Neptune in their oppositions in I88I, by A. Sowitsch.-Determination of the mass of Jupiter by means of observations of the reciprocal distances and the directions of his satellites, by $\mathrm{O}$. Backland.-Action of zinc-methyl on chloral, by B. Rizza.-De Marci Antonini Commentariis, by A. Nauck, -Hydrological researches (continued), by C. Schmidt.

Zeitschrift für wissenschaftliche Zoologie, Bd. 37, Heft. 2, September 27, 1882, contains : Contributions to the anatomy of Ankylostoma auodenale (Dubini) = Dochmins duodenalis (Leuckart), by Wm. Schulthess (plates I I and I2). - On the ontogeny of Reniera filigrana (O. Schmidt), by Wm. Marshall (plates $\mathrm{I}_{3}$ and 14).-Contribution to a knowledge of the structure and functions of the heart in osseous fishes, by Kasem-Beck and J. Dogiel, of Kasan (plates 15 and I6), - Contribution to a knowledge of the cestoid worms, by Dr. Z. von Roboz (plates 17 and r8).-Comparative embryological studies of Elias Metscbnikoff, No. 3, on the gastrula of some Metazoa (Echinus miliotuberculatus, Lineus lacteus, Phoronis hippocrepina, Polygordius flavocapitatus, Ascidia mentula, and Discoporella radiata ( $\rho$ lates 19 and 20).

Morphologisches Fahrbuch eine Zeitschrift für Anatomie und Entrevickeluinysgeschichte, bd. viii. heft 2, 1882, contains:-Contribution to the Angiology of the Amphibia, by Dr. J. E. V. Boas (with plates 6 to 8).-On the nasal cavities and the lachrymo-nasal canals in the amniotic vertebrata, by Dr. G. Born (with plates 9 and 10 ). - New foundations for a knowledge of cells, by Dr. A. Rauber (with plates II-14). -Observations on the development of the crown of tentacles in Hydra, by $\mathrm{H}$. Jung.

\section{SOCIETIES AND ACADEMIES Lonnon}

Linnean Society, November 2.-Sir J. Lubbock, Bart., in the chair.-Prof. J. C. Ewart, G. Fry, and Lord Walsingham were elected Fellows of the Society.-Mr. A. P. W. Thomas drew attention to a series of specimens under the microscope, and diagrams illustrative of the life history of the Liver Fluke (Fasciola hepatica). His experiments show that the embryos of the Fluke, as free Cercariæ, burrow into and develop within the body of Linnans truncatulus, and thereafter pass with the herbage into the stomach, and ultimately liver of the sheep. Salt added to the sheep's diet is found to act as a prophylactic. -Mr. W. T. Thiselton Dyer exhibited specimens and made remarks on the plant producing Cassia lignea, and on the native implements used in the collection and preparation of the Cassia bark in Southern China.-Mr. C. T. Druery showed two proliferous forms of Athyrium filix fomina, a family hitherto remarkalle for its unproliferous nature. Both examples appeared simultaneously; not the least significant feature being their extreme precocity, since bulbil-bearing ferns are proliferoususually only on their mature fronds.-Mr. F. Crisp exhibited preparations in illustration of the views of Drs. Loew and Bokormy on the difference between dead and living protoplasm, viz. the power of the living organism to reduce silver salts in a very dilute alkaline solution.-Prof. E. Ray Lankester exhibited and made remarks on a series of marine organisms dredged by him, last summer, in the fjords of Norway. Of these may be mentioned a branch of Paragorgia arborea, three feet across, specimens of the same in spirit, as also of Lophelia prolifera, Amphiheria ramea, Stylaster norvegicus, Primnoa lepadifera, and Paramuricia ramosa, both dried, and also with the polyps preserved in spirit. The collection also included some very large new forms of Foraminifera specimens of Rhizocrinus Lofotensis, of the aberrant mollusca Neomenia and Chatoderma, and of Rhabdopleura Normani, besides a large series of sponges and Asteroidea.-Mr. T. Christy exhibited a living specimen of the Japanese peppermint plant, which yields the Menthol of commerce, this being the first plant grown in this country. Mr. Holmes mentioned that although this mint did not differ in botanical characters from Mentha arvensis, it had a strong peppermint odour and flavour, which were not found in the specimens growing either in Europe or India. He therefore proposed that the plant should be named $M$. arvensis, var. piperaneus by way of distinction.-Mr. J. G. Baker showed a specimen of Lycopodium complanatum collected in Skye by Prof, Lawson.Sir J. Lubbock then read his tenth communication on the habits of ants, bees, and wasps, a notice of which appeared in our last issue, p. 46.-A paper was read on medicinal plants of North-West Queensland, by W. E. Armit. Among these is a species of Aristolochio and a Croton; also Grewia polysama, a specific for dysentery; Careya arborescens, used for poultices; Erythrece australis, and Andropogon citriodora, tonics in febrile complaints; and Eu. phorbia pilulifera and Datura australis, valuable in cases of asthma. - A remarkable malformation of the leaves of Beyeria opaca, var. linearis, from Yorkes Peninsula, South Australia, was described by $\mathrm{Mr}$. Otto Tepper.-Dr. F. Day exhibited specimens in illustration of a paper read by him, on variation in form and hybridism in Salmo fontanalis.-Mr. H. N. Ridley afterwards read some teratological notes on a Carex, a Grass, and an Equisetum

Zoological Society, November I4.-Prof. W. H. Flower, F.R.S., president, in the chair. - A letter was read from Mr. E. L. Layard respecting a specimen of Schanicola platyura received by the British Museum from the late Mr. Cuming.Prof. F. Yeffrey Bell exhibited some examples of Lymnaus truncatulus, lately discovered to be the chief host of the larva of the sheep-fluke.-Prof. Flower exhibited and made remarks upon the skull of a young chimpanzee from Lado, in the Soudan, sent to him by Dr. Emin Bey, which exhibited the deformity called "Acrocephaly," associated with the premature closure of the fronto-parietal suture.-Mr. H. E. Dresser exhibited and made remarks on specimens of Melittophagus boehmi, Reichenow, and Merops dresseri, Shelley, which he showed to be identical. A communication was read from Mr. W. A. Forbes containing some supplementary notes on the anatomy of the Chinese Water Deer (Hydropites inermis). - A communication was read from the Rev. L. Baron, containing notes on the habits of the AyeAye of Madagascar in its native state.-Mr. G. E. Dobson read a paper on the natural position of the family Dipodidx, which he maintained to be with Hystricine, and not, as generally supposed, with the Murine Rodents, and to be most nearly allied to the Chinchillidæ.-Prof. F. Jeffrey Bell read a paper on the genus Psolus, relating its literary history, and giving an enumeration of the described species. Attention was directed to the extensive distribution of $P$. fabricii, and to the variations during growth. After the description of other known forms, two new species ( $P$. peronii and $P$. ambulata) were described; for the latter a new sub-genus was suggested, and the genus itself was divided into three sub-generic groups. - A second paper from Prof. Bell contained an account of a Crinoid from the Straits of Magellan, obtained by Dr. Coppinger during the voyage of H.M.S. Alert, which was referred to a new variety of Antedon eschrichti of the Arctic seas. - Mr. W. H. Neale read some notes on the natural history of Franz-Josef Land, as observed in 1881-82, during the stay of the Eira expedition in that land.Dr. Gwyn Jeffreys read the fifth part of his list of the Mollusca procured during the expeditions of H.M.S. Lightning and 
Forcupine. This part, which embraced the species from the Solenoconchia to the Calyptræidæ, comprised sixty-nine species, of which twenty two were now for the first time described or figured. The gengraphical, hydrographical, and geological range of all these species was given, as in his former papers; and the author especially noti.ed the points of agreement between the deep-water Mollusca, from the American and European expeditions.

Physical Society, November 11.-Prof. Clifon, president, in the chair.-Prof. Rowland, of Baltimore, exbitited a number of his new concave gratings for giving a diffraction spectrum. He explained the theory of their action. Gratings can be rnled on any surface if the lines are at a proper distance apart and of the proper form. The best surface, however, is a cylindrical or spherical one. The gratings are solid slabs of polished speculum metal ruled with lines equidistant by a special machine of Prof. Rowland's invention. An account of this machine will be published shortly. The number of lines per inch varied in the specimens shown fro $n 5000$ to 42,000 , but higher numbers can be engraved by the cutting diamond. One great advantage of their use is that the relative wave-lengths can be meacured by the micrometer with great accuracy. The author has designed an ingeniousmechanicalarrangement for keeping the photographic plates in focus. In this way photographs of great distinctness can be obtained. Prof. Rowland exhibited some ro inches long, which showed the E-line doubled, and the large B groups very clearly. Lines are divided by this method which have never been divided before; and the work of photographing takes a mere fraction of the time formerly $r$ : quired. A photographic plate sen.itive throughout its length is got by means of a mixture of eocene, iodised collodion, and bromised collodes. Prof. Rowland and Capt. Abney, R.E., are at present engaged in preparing a new map of the whole spectrum with a focus of 18 feet. In reply to Mr.Hilgar, F.R.A.S., he stated that if the metal is the true speculum metal used by Lord Rosse, it would stand the effects of climate he thought; but if too much copper were put in it might not. In reply to Mr. Warren de la Rue he said that 42,000 was the largest number of lines he had yet required to engrave on the meial.Prof. Guthrie read a letter from Capt. Abney, pointing out Prof. Rowland's plates gave clearer spectra than any others they were free from "ghosts" caused by periodicity in the ruling ; and the speculum metal had no particular absorption. Prof, Dewar, F.R.S., observed that Professor Liveing and he had been engaged for three years past in preparing a map of the ultra-violet spectrum, which would soon be published. He con sidered the concave gratings to make a new departure in the subject, and they would have greatly facilitated the,preparation of his map.-Mr. W. R. Browne then read a paper on the conservation of energy and central forces. He showed that the doctrine of the conservation of energy necessarily involved central force and could not be proved unless on the assumption of a system of central forces. This involved the hypothesis of Boscovich that matter consists of a collection of centres of force, and the author criticised the objections of Clerk Maxwell, Tait, and others to Boscovich's theory. The paper will appear in the Transactions of the Society. - Prof. S. P. Thompson read some historical notes on physics, in which he showed that the voltaic arc between carbon points was produced by a Mr. Etienne Gaspar Robertson (whose name indicates a Scotch origin) at Paris in $\mathbf{1 8 0 2}$. This reference is found in the Fournal de Paris for that year. Laboratory note-books at the Royal Institution, however, are said to show that Davy experimented with the arc quite as early. The experiment usually attributed to Franklin of exhausting air from a vessel of water "off the boil" and causing it to boil afresh, is found in Boyle's "New Experiments touching the Spring of the air. Prof. Thompson also exhibited an early Reis's telephone, made by Philip Reis in 186I at Frankfort, and designed to transmit speech. It was modelled on the human ear, one form of transmitter being a rudely-carved wooden ear, with a tympan, haxing a platinum wire behind, hard pressed against a platinumtipped adjustible spring. Prof. Thompson showed by various proofs that words were actually sent by that and similar apparatus.

Met eorological Society, November I5.-Mr. J. K. Laughton, F.R.A.S., president, in the chair.-Eleven new Fellows were elected, viz. Rev. J. Brunskill, F. B. Buckland, C. F. Casella, W. H. M. Christie, F.R.S., A. Cresswell, R. S. Culley, C. Morris, O. L. O'Connor, H. Parker, F.Z.S., A. Rowntree, and D. R. Sharpe.-The Fapers read were: On certain types of British weather, by the Hon. Ralph Abercromby, F.M.S. The author shows that there is a tendency of the weather all over the Temperate Zone to occur in spells associated with certain types of pressure distribution. In Great Britain there are at least four persistent types-the southerly, the westerly, the northerly, and the easterly. In spite of much fluctuation, one or other of these types will often continue for weeks together, and tend to recur at the same date every year. The value of the recognition of type groups is shown in the following ways:-(I) They explain many phenomena of weather and many popular prognostics; (2) in some cases they enable forecasts to be issued with greater certainty and for a longer time ahead; (3) we can by their means correct statistical results by giving the real test of identity of recurrent weather which no single item such as heat, cold, rain, \&c., can do ; (4) they enable us to treat such geological questions as the influence of changing distribution of land and sea on climate in a more satisfactory manner than any other method.-On the use of kites for meteorological observation, by Prof. E. Douglas Archibald, M.A., F.R.S. In this paper the author advocates the use of kites for meteorological observation, and describes the mode in which they may be best flown so as not to be mere toys, but scientific instruments, capable of ascending to great heights, remaining steady in currents of varying velocity, and of being manipulated with ease and rapidity by the observer. -The meteorology of Mozufferpore, Tirhoot, 188r, by Charles N. Pearson, F.M.S.

Institution of Civil Engineers, November I4. - The president, Sir W. G. Armstrong, C. B., F.R.S., in the chair.-The paper read was on "Recent Hydraulic Experiments," by Major Allan Cunningham, R.E., Honorary Fellow of King's College, London.

\section{BERLIN}

Physical Society, October 3.--Prof. Rœber in the chair.Dr. Kœnig had already reported in a previous session on the Leukoscope, designed and constructed by Prof. Helmholtz, and communicated now the results of his further experiments with this instrument. It consists essentially of a calc-spar-rhomboid, a plate of quartz, and a Nicol's prism. A luminous pencil entering the calc-spar is split up into two rays polarised at right angles which traverse the quartz-plate and the Nicol. When spectroscopically analysed, these rays show two spectra of absorption-bands, in the spectrum of the one pencil at foints where in the spectrum of the other pencil the intensity is undiminished, and vice versâ, so that the two spectra superposed would give a continuous spectrum. The number of bands increases with the thickness of the quartz, and they are shifted by rotating the Nicol. The modus operandi then is to put in a quartz plate of such a thickness, and to rotate the Nicol so much that in each of the spectra the colours that are not blotted produce together white light. When different sources of light are examined with the leukoscope, the different amounts of rotation of the Nicol are required for effecting a conformity of the two images, the relative quantity of certain rays being different in every different light, the prevailing tint belonging therefore to the one, and not to the other spectrum. Further experiments having proved that the plate of quartz could remain unaltered, the rotation angles of the Nicol were a gauge of the quality of colours of the light examined. Dr. Kœnig has tried in this way a series of sources of light, and found the angles wanted for homogeneity of the white images to be as follows :With stearin candles $=7 \mathrm{I}^{\circ} \cdot 20$; with gaslight $=7 \mathrm{I}^{\circ} \cdot 5$; with electric arc light $=79^{\circ}$; with magnesium light $=86^{\circ}$; with solar light $=90^{\circ} .5$; with burning phosphorus and Drummond lime-light the angles were between gas and electric-arc light. The succession of the sources of light thus stated coincides strikingly with the result; of spectro-photometric measurements of Prof. Pickering. The fact that the magnesium light is more like the solar light than the electric arc light quite corresponds with the known fact that of the aniline dyes, scarcely distinguishable by gas-light, the greatest part can be perceived by electric light, but not all, viz, the so-called bronze hues; whereas by the magnesium light they are all as well distinguished as by solar light. Furthermore Dr. Koenig has made many measure. ments with the leukoscope on different electric incandescent lights; with Swan's lamp and Edison's Iamp he gave the results of his experiments in tables in which the strength of the current, the intensity of light, and the angles of the leukoscope were indicated. From these numbers it follows that luminosity augments at first at a much greater rate with increasing strength of current than the latter; by doubling the strength of the current 
the illuminating power was increased about sixty-fold. The angles of the leukoscope became likewise greater with the rising intensity of the light in such a manner that a curve traced with the light intensities as abscissæe and the angles as ordinates is concave to the abscissæ and approaches assymptotically a maximum near $78^{\circ}$, an angle approximately equal to the angle $\left(79^{\circ}\right)$ of the glowing carbons of the electric arc light. The measurements with a Siemens' incandescent lamp gave also numbers which could be represented by a similar curve.

\section{PARIS}

Academy of Sciences, November I3.-M. Jamin in the chair.-The following papers were read:-Results of experiments viade with electric candles at the Exhibition of Electricitv, by M. Allard and others. The systems examined, those of Jablochkoff, Jamin, and Debrun, now produce nearly the same ecnnomical results.-On the reproduction of osmides of iridium, by M. Debray. Osmium and iridium may crystallise together in all proportions, without the form of their combination being altered. They are then isomorphous. And natural osmides may be true isomorphous mixtures, belonging to the cubic system, notwithstanding the hexagonal appearance of certain varieties (but this view is given with reserve, natural osmides being of crmplex composition). - Report to the Bureau des Longitudes on the approaching eclipse of May 6, I883, by M. Janssen. -Note on the telluric lines and the spectrum of aqueous vapour, by M. Janssen. He recalls his own method, based on study of the spectrum of water vapour in a tube; he is now working at it. The telluric lines (so called by him) are historically quite different from the bands of Brewsier; (an expression of M. Cornu's seemed to affirm their equivalence.) -On the currents produced by nitrates in igneous fusion, in contact with red hot carbon, by M. Brard. Owing to the tendency of fused nitrates to spread in heated bodies, a current may be had if a short carbon rod with one end put in the nitrate has only the other end incandescent; also if fused nitrate in a metal capsule is placed on burning carbon (the nitrate soaks through, so that the outer surface of the capsule becomes quite moist); indeed, such a capsule merely hung over a centre of combustion gives a current (from the nitrate bath to the outer surface of the capsule). The effect is improved by putting plumbago, or lampblack, on the outside, and covering all with metallic foil. Nitrates kept in fusion have great fixity.-Chemical studies on the white beet of Silesia (continued), by M. Leplay.-Obervations made during the total eclipse of the sun of May I7, 1882, by M. Tacchini. He gives a résumé of his memoir, which will shortly appear.On Abelian differential equations in the case of reduction of the number of periods, by M. Picard.-On a theorem of M. Tisserand, by M. Stieltjes. - Extension of the problem of Riemann to hypergeometric functions of two variables, by $M$. Goursat.-On the development of functions in series of other functions, by M. Hugoniot.-On the exactness of measurements made with the mercury thermometer, by M. Crafts. The pressure (of the air) has little influence. Permanent elevation of the fixed points, produced at a high temperature, preserves the thermometer against the influence of heat, in this respect, at lower temperatures.-Conclusions of hydrodynamic experiments in imitation of phenomena of electricity and magnetism ; reply to a note of M. Ledieu, by M. Decharme. The theory of waves seems to him to be "the secret of nature," and he places the results of his experiments against the unverified ideas of M. Ledieu.-Electric deformations of quartz, by MM. Jacques and Curie. With delicate apparatus, they observed and measured such deformation when a charge was given to two pieces of tin at the opposite ends of the electric axis. The dilatations measured agreed satisfactorily with those calculated from the electricity liberated.-On the electrification of air, by M. Mascart. In the Amphitheatre of the College of France he electrified the air by discharging a Leyden jar with a flame, during ten seconds; another flame, $8 \mathrm{~m}$. off, communicated with an electrometer in an adjoining hall. The maximum defiection in the latter was reached in about a quarter of an hour; then there was slow diminution, but after two hours I-2oth of the maximum still remained. The electrified gas probably rises and is diffused like smoke. To study the lower atmospheric layers, the potential should be de. termined in a large inclosure formed of metallic netting, connected with the ground.-On atmospheric nitrification, by MM. Muntz and Aubin. A constant absence of nitrates in meteoric waters was observed at the top of the Pic du Midi (nearly
$3000 \mathrm{~m}$.). A comparison of thunderstorms shows the summit to be generally above them. Atmospheric nitrification is probably produced in the lower regions of the air.-On the decomposition of phosphates at a high temperature by sulphate of potash, by M. Grandeau.-Point of solidification of various mixtures of naphthaline and stearic acid, by M. Courtonne.On œnocyanine, by M. Maumené.-On the cause of liberation of oxygen from oxygenated water by fibrine; influence of hydrocyanic acid exhausting the activity of fibrine, by $M$. Béchamp. He shows that the fibrine loses somewhat; and that it no longer decomposes oxygenated water nor fluidifies starch, nor gives bacteria.--On the signification of the polar cells of insects, by M. Balbiani.-On the vaso-dilator reflex of the ear, by M.M. Dastre and Morat.-Phenomena of death from cold in Mammalia, by MM. Richet and Rondeau. The respiratory and cardiac functions may be suspended for half an hour, without death certainly ensuing. (Rabbits, shaved (rasés), were inclosed in flexible tin tubes, through which flowed salt water cooled to $-7^{\circ} \mathrm{C}$.). - Analogies and differences between curare and strychnine, as regards their physiological action, by M. Couty.-On the causes of migration of sardines, by M. Launette. Each migration is normally under the two conditions of food and temperature combined.-Contribution to the geological history of the iron of Pallas, by M. Meunier.

\section{VIENNA}

Imperial Academy of Sciences, October 12.-V. Oppolzer, finding the reduction to infinitesimal arcs of vibration at pendulum-observations.-H. Krenter, computation of the trajectory of the comet $x 77 \mathrm{r} .-\mathrm{V}$. Barth and T. Schreder, on the behaviour of benzoic acid if dissolved in caustic potash. $-\mathrm{N}$. Jferz, the theory of computations of the trajectory of a comet.

October 19.-K. v. Lendenfeld, on a new self-registrating thermometer. $-\mathrm{V}$. Oppolzer, on an eclipse of the sun mentioned by Archilochos. -W. Demel, on the Dopyrlerite of Ausser (Styria).-W. Gintl and F. Reinitzer, on the constituents of the leaves of Fraxinus excelsior, $\mathrm{L}$.

\section{CONTENTS}

THE CHA

ALlenger Reports

UR BOOK SHELF:-

Brown's "Practical Chemistry" • • • • • . 75

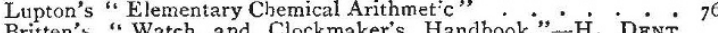
GARDNRR. . . . . . . . . . . .

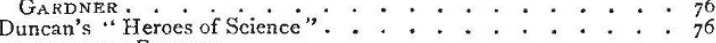
LKTTERS TO THE EDITOR:-

Physics of the Earth's Crust.-Rev. O. Fisher . . . . . . . 76

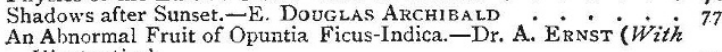
Illustration)

The Comet.-B. J. Hopkins

Soda Flames in Coal Fires.-Major J. HerscheL

Complementary Colours-A Mock Sunset.-I. H.

A Lunar Halo.- J. RAND CAPRON

A Correction.-E. L. LAYARD

Thomson's Mouse-Mill Dynamo.- J. T. BotTomLEY

Weather Forecasts. -CHARLES W. HARDING * * * * 79

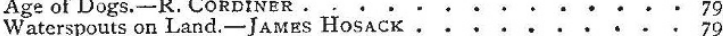

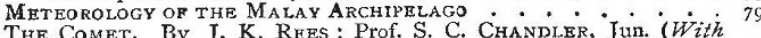

The Comet. By J. K. Rhes ; Prof. S. C. Chandler, Jun. (With

Influence of "Environment" upon Prants. By W. T. Thiselton DYER, C.M.G., F.R.S.

The Magnetir. Storm and Aurora. 'By W. H. $\dot{M}^{\circ}$. Curistie:

F.R.S. Prof C. PrazzI SMYTH, Astronomer Royal for Scotland;

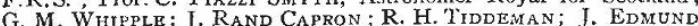

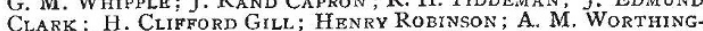

Clark: H. CLIFFORD GILl; HENRY RoBINSON; A. M. WORTHING-

TON ; THOS. GWYN ELGER; MISS C. ROSE RN ST C. H.

ROMANES; E. BROWN; FRANK STAPLETON, Rev. STEPHEN H.

SAXBY; Dr. HUBBRT AIRY : Major J. HERSCHEL; A. S. P.; H. D. TAYLOR; T. P. BARKAS: W. MAKRIG JONES; GEORGE RAYLEIGH Ticars; Prof. J. P. O'REILly; JoH Hydra. By Prof. E. Rax

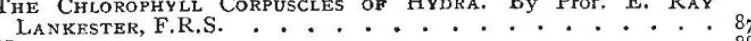
NoTES

NoTES Nit:-

Apparent Bird-tracks by the Sea-Shorc . . . . . . . . . 91

Australian Freshwater Sponges . . . . . . . . . . . . . gr

Earth-worms in New Zealand
The Genesis of the Hypophysis in Petromyzon Planeri $\dot{*}^{*} \cdot \dot{*}^{*} \cdot \mathbf{9}^{\mathrm{I}}$

Formic and Acetic Acid in Plants . . . . . . . . . . . 9r

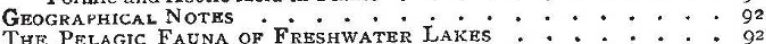

The Pelagic Fauna of Freshwater Lakes $: \cdot v^{*} \cdot v^{*}: 9^{2}$

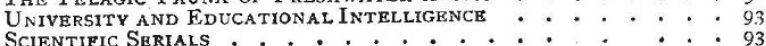

Socibties AND ACAdEMIEs. . . . . . . . . . . . . . 94 